
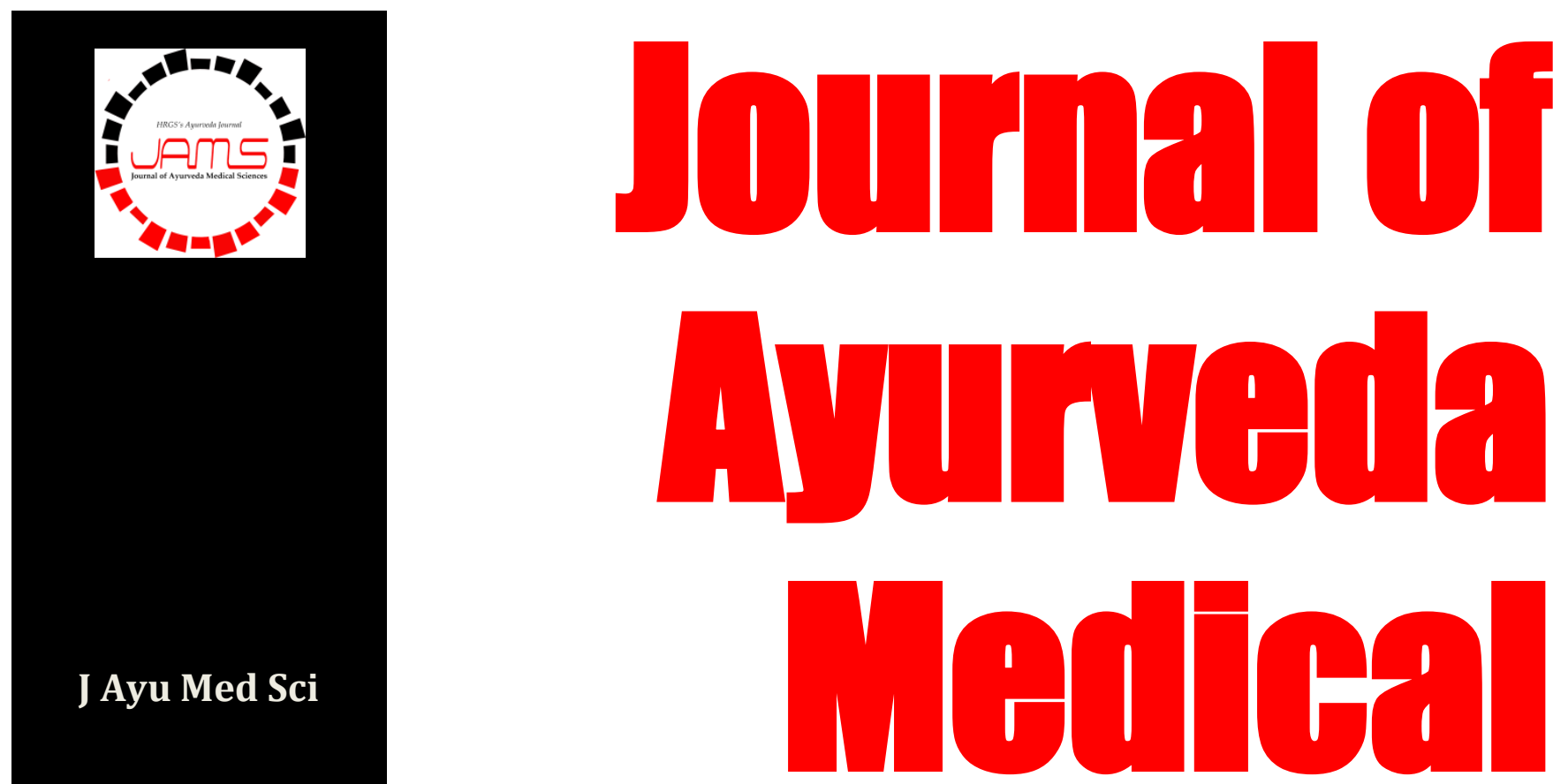

Quarterly Journal for

Rapid Publication

of Researches

in Ayurveda

and Other Traditional

Medicines

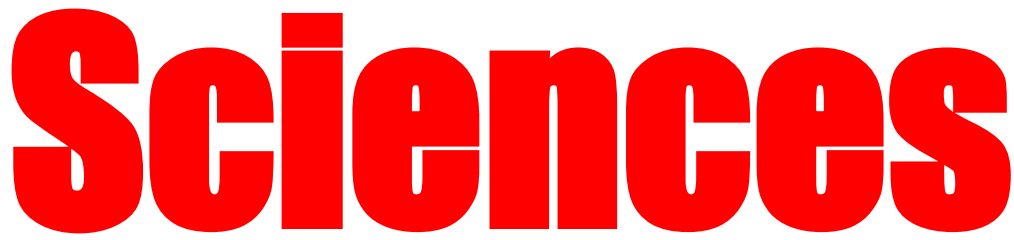

www.jayumedsci.com

ISSN 2456-4990

\title{
Review of Anti-cancer Activity of Metals and Minerals
}

Nano-technology is an emerging science having a promising role in treating a number of diseases including cancer. Bhasma can be comparable to nono-medicine or can be considered as ethno-nanomedicine. Arbudaharayogas (anticancer drugs) mentioned in the classical textbook of Rasayoga Sagar and research works published in various journals showing the effect of nanoparticles prepared by different method in various types of cancer have been documented in this study. It can be concluded that Bhasmas play a strong role in the emerging era of nano-medicine and can be considered as an efficient therapeutic cure in dreadful disease like cancer.

Ruhila et al.

J Ayu Med Sci 2018; Jul-Sep 3(3): 405-12.

DOI 10.5530/jams.2018.3.20 


\section{Review of Anti-cancer Activity of Metals and Minerals}

\section{Anu Ruhila*, Pramod Yadav, Galib Ruknuddin, Pradeep Kumar Prajapati}

All India Institute of Ayurveda, Sarita Vihar, New Delhi 110076, India.

\begin{abstract}
Introduction: Cancer has been considered as the second leading cause of death worldwide. The current interventions employed to combat the disease includes chemotherapy, radiation therapy, surgery and immunotherapy. Though these therapies are considered for treating the dreadful disease, they does not promise perfect cure and also have devastating effect on the quality of life of cancer survivors. Nano-technology is an emerging science having a promising role in treating a number of diseases including cancer. Various works has been done by different scholars in the field of nanotechnology and its role in cancer using varied techniques and procedures. In Ayurveda, the Herbo-metallic or Herbo-mineral compound formulations, Bhasmas, can be considered as biologically produced nanoparticles. Method: In this present paper a review has been done to collate the evidences related to anti-cancer activity of nanoparticles of various metals and minerals along with it, an effort has been made to recapitulate all the Arbudaharayogas (anticancer drugs) mentioned in the Classical textbook of Rasayoga Sagar. Result and Conclusion: Ayurvedic Bhasmas can play a strong role in the emerging era of nano-medicine and can serve as an excellent tool for the development of nano-medicine, to be an efficient therapeutic cure in dreadful disease like cancer. There is a lack of clinical trials and publications by the practising physicians, which is a matter of great concern.
\end{abstract}

KEYWORDS Nanotechnology, Nanomedicine, Cancer, Arbudahara Yogas.

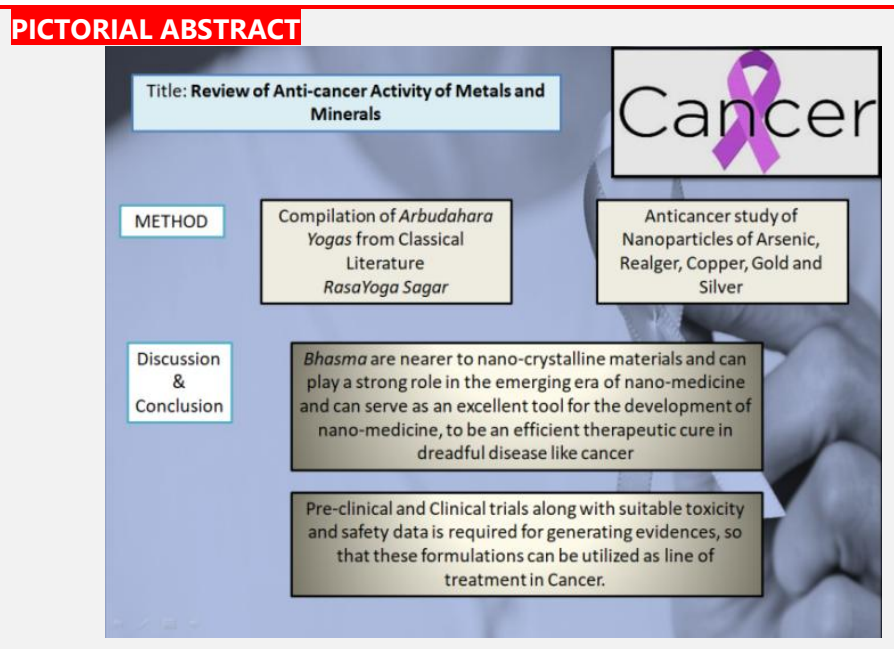

ARTICLE HISTORY Received 09.01.2019 Accepted 28.03.2019

CORRESPONDENCE Dr. Anu Ruhila, PG Scholar, Department of Rasa Shastra \& Bhaishajya Kalpana, All India Institute of Ayurveda, Sarita Vihar, Mathura Road, New Delhi 110076, India. Email: anuruhela24@gmail.com

CITE THIS RESEARCH AS Ruhila A, Yadav P, Ruknuddin G, Prajapati PK. Review of Anti-cancer Activity of Metals and Minerals. J Ayu Med Sci 2018;3(3):405-12.

DOI 10.5530/jams.2018.3.20

\section{INTRODUCTION}

Cancer is a term for a large group of diseases characterised by the growth of abnormal cells beyond their usual boundaries that can then invade adjoining parts of the body and/or spread to other organs ${ }^{[1]}$. Cancer can affect almost any part of the body and has many anatomic and molecular subtypes that require specific management strategies. The most common types of cancer in males are lung, prostate, colorectal and stomach cancer. In females commonly found cancers are breast, colorectal, lung and cervical cancer, whereas in children the incidence of acute lymphoblastic leukemia and brain tumors are more ${ }^{[1]}$.

The slot of major public health burden in both developed and developing countries has been acquired by Cancer.It is the second leading cause of death globally after the cardiovascular diseases.In 2018, around 18 million people were suffering from cancer accounting for a death of about 9.6 million people worldwide. It is predicted that the number of cancer cases will rise up to 29 million by the year $204.0^{[2]}$.
In India, the number of people living with cancer is 22 million; with an increase in the number of new cases in both sexes is 1.15 million in all ages having an incidence rate of $89.4 \%$.The number of cancer related deaths accounts for over 7.8 lakhs nationwide ${ }^{[3]}$. The increase in the prevalence of risk factors such as use of tobacco, alcohol, unhealthy diet and physical activity along with rapid growth in population and aging are the contributing factors towards the rise in number of incidences and mortality related to cancer.

Current therapies employed for the treatment of cancer include chemotherapy (cytotoxic anti-neoplastic drugs), radiation therapy (use of ionizing radiation), immunotherapy and surgery. These methods have been accepted and practiced for decades, but they have their drawbacks and side effects. There is a need to search for newer options of cancer therapy.

Ayurveda offers medicines and treatment which can easily be incorporated with the main stream of cancer medicines. Ayurveda opines that there is not a single substance in the 
Universe which does not have a potential to be used as a drug, provided it should be used judiciously by the physician where it is required. Immunomodulatory and antioxidant properties of various medicinal plants are responsible for their anticancer activities. Phytochemicals such as vitamins (A, C, E, and K), carotenoids, terpenoids, flavonoids, polyphenols, alkaloids, tannins, saponins, pigments, enzymes and minerals have been found to elicit anticancer activities ${ }^{[4]}$.Plants are promising and effective source of anticancer agent and over 60\% anticancer agents are derived from natural resources including plants, marine organisms and microorganisms ${ }^{[5]}$.An estimate of around 114,000 extracts of plants, marine organism and micro-organisms has been screened successfully by The National Cancer Institute for their anticancer activity ${ }^{[6]}$. Natural products or the use of plant-derived products in the treatment of cancer will help in reducing adverse and toxic side effects and also in combating the dreadful disease.

\subsection{Cancer in Ayurveda}

The earliest description of malignancies was described in AtharvaVeda (2200 BC) as Apachi which in later period, the term Arbuda(Cancer)was coined that are described as swellings, which are globular, fixed, large and deeply-seated, slow growing, little painful, non suppurative and appear like a fleshy mass. Arbudais classified as Raktaja, Mamsaja, and Medoja (i.e. arising from vitiated Dhatus or blood, muscle, or adipose tissues) ${ }^{[7]}$. Arbudas that arise in specific organs are named accordingly. The diseases and disorders simulating cancer described in Ayurveda are Arbuda, Asadhya Vrana, Mamsajaosthroga, Alas, MamsaKacchapa, Galaugha, Asadhya Galaganda, Tridoshajagulma, Asadhya Gulma, Asadhya Udaroga, Sahaja Arsha, Kshataja Kasa, Kshayaja Kasa, Lingarsha, Kshataja Visarpa, Tridoshaja Nadivrana, Asadhya Pradara and Asadhya Kamla ${ }^{[8]}$.

Rasashastra is one the most important branch of Ayurveda dealing with the minerals, metals, precious stones, certain poisonous herbs and their processing. The Rasaushadh is are very potent in eliminating dreadful diseases and also for rejuvenation purposes. They occupied superior status among the Ayurvedic medicines due to their small dose, quick action, tastelessness, effectiveness on dreadful diseases and long shelf $\operatorname{life}^{[9]}$.

Bhasmas are herbo-mineral-metallic compounds which are of size of nano-dimensions (usually 5 to $50 \mathrm{~nm}$ ), and having Rasayana and Yogavahi properties indicating its immunemodulation and target drug delivery characteristics ${ }^{[10]}$. Nanoparticles are the particles with length that range from 1 to $100 \mathrm{~nm}$ in two or three dimensions ${ }^{[1]}$.The rapid expansion in nanomaterial research will increase the future prospect of the disease which will prove to be beneficial to mankind.

\section{MATERIALS AND METHODS}

Classical text Rasayoga Sagar ${ }^{[12]}$ is a compilation of all the formulations containing metals and minerals described in different classics. For present study, it was hand-searched for the herbo-minerals and herbo-metallic preparations indicated specifically in Arbuda. Further, the available published literature was also screened for the anti-cancer activities of nano-medicines in the databases like PubMed, Scopus etc.

\section{RESULTS}

\subsection{Arbuda Formulations mentioned in Rasayoga Sagar}

On scrutinizing the total number of yogas (Table 1), it is noticedthat the rasadravyas such as Manhashila and Hartala (arsenicals), Tamra (copper), Swarana (gold), Rajata (silver) are widely used in the therapeutics. Hence an attempt has been made to review and collect the data published on the nano-medicines prepared from these drugs with their significant role in treating cancer.

\subsection{Arsenic and its compounds}

Arsenicals, a group of minerals, are an integral part of Ayurveda therapeutics comprising Haratala (Arsenic trisulphide), Manahshila (Arsenic disulphide) and Somala (Arsenic trioxide) mentioned with wide range of their uses. Somal, Shankiya, Gauripashana, Shankhavisha etc. are its synonyms and it is chemically arsenic trioxide $\left(\mathrm{As}_{2} \mathrm{O}_{3}\right)$ or white arsenic. It is to be used in therapeutics after the shodhana process (purification procedures) and is said to possess Rasayana properties.

In a study, 15 Acute Promyelocytic Leukemia (APL) patients at relapse were evaluated after administering $\mathrm{As}_{2} \mathrm{O}_{3}$ at a dose of $10 \mathrm{mg} / \mathrm{d}$. Fourteen out of 15 patients achieved complete remission with $\mathrm{As}_{2} \mathrm{O}_{3}$ treatment alone or in combination with low-dose chemotherapeutic drug or all-trans retinoic acid (ATRA) $)^{[13]}$. Thehigh synergistic effect was found on administrating the combination of arsenic trioxide (As) and IFN (alpha-interferon) in Adult T-cell Leukemia (ATL) derived cell lines and control cell lines, resulting in the inhibition of proliferation and DNA synthesis, modification of the cell cycle phases, and induction of apoptosis ${ }^{[14]} \cdot \mathrm{As}_{2} \mathrm{O}_{3}$ inhibited dosedependent proliferation of myeloid and lymphoid culture cell lines but showed different effects on viability of these cell where it could inhibit leukemia and lymphoma cell proliferation by 
induction of cell apoptosis or by cell cycle arrest ${ }^{[15]}$. The effects of $\mathrm{As}_{2} \mathrm{O}_{3}$ on the growth and gene expression of cells in $\mathrm{HCE} 16 / 3$ cell line (HPV16 DNA-immortalized human cervical epithelial cells) model showed selective inhibition of expression of viral oncogene suggesting $\mathrm{As}_{2} \mathrm{O}_{3}$ an agent for treating $\mathrm{HPV}$-associated tumours $^{[16]}$. On treating the oesophageal carcinoma using human EC8712 cell line, As2O3 showed inhibition of growth and survival of tumour cells by induction of apoptosis at a half dose effect $\left(E D_{50}\right)$ of concentration $1 /$ microM $^{[17]}$.

\section{Table 1. Formulations indicated in Arbuda (mentioned in Rasayoga Sagar)}

\begin{tabular}{|c|c|c|c|c|c|c|c|c|c|c|c|c|c|c|c|c|c|c|c|c|c|}
\hline Formulations & 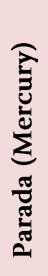 & 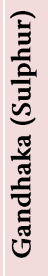 & 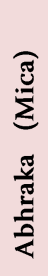 & 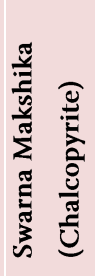 & 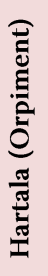 & 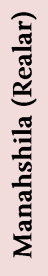 & 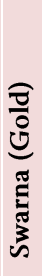 & 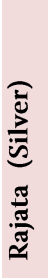 & 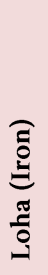 & 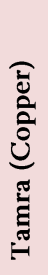 & 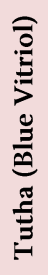 & 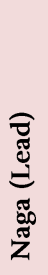 & ڤั) & 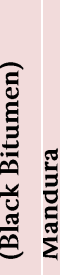 & 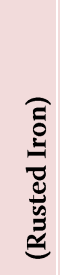 & 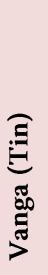 & 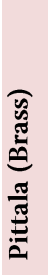 & 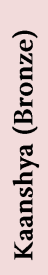 & 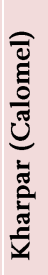 & 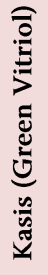 & 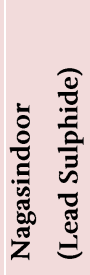 \\
\hline Amavatari Rasa & + & + & - & - & - & - & - & - & + & + & + & - & - & & - & - & - & - & - & - & - \\
\hline Chandra-Prabha Vati(Ii) & - & - & - & + & - & - & - & - & + & - & - & - & + & & - & - & - & - & - & - & - \\
\hline Dinardha Rasa & + & + & + & + & + & + & + & + & + & + & + & + & + & & + & + & + & + & + & + & + \\
\hline Hemadri Rasa & + & + & + & - & - & - & - & - & - & - & - & + & - & & - & - & - & - & - & - & - \\
\hline Kanakagiri Rasa (Ii) & + & + & + & - & - & - & + & - & + & - & - & + & - & & - & - & - & - & - & - & - \\
\hline Kamakala Vati & - & - & - & + & - & - & - & - & + & - & - & - & + & & - & - & - & - & - & - & - \\
\hline Laxminarayana Rasa (Iii) & + & + & + & - & - & + & + & + & + & - & - & + & - & & - & + & - & - & - & - & - \\
\hline Lavanga Paka & + & - & - & - & - & - & - & - & - & + & - & - & - & & - & - & - & - & - & - & - \\
\hline Manikya Rasayanama (Ii) & - & - & - & - & - & - & + & + & - & - & - & - & - & & - & - & - & - & - & - & - \\
\hline $\begin{array}{l}\text { Mohadrivajra } \\
\text { Pata Rasa }\end{array}$ & + & + & + & - & - & - & - & - & - & - & - & + & - & & - & - & - & - & + & - & - \\
\hline Nityanada Rasa & + & + & - & - & + & - & - & - & + & + & + & - & - & & - & + & - & + & - & - & - \\
\hline $\begin{array}{l}\text { Nripatti } \\
\text { Vallabha Rasa }\end{array}$ & + & + & + & - & - & - & - & - & + & + & - & - & - & & - & - & - & - & - & - & - \\
\hline $\begin{array}{l}\text { Someshwara } \\
\text { Rasa (I) }\end{array}$ & + & + & + & - & - & - & - & - & + & - & - & - & - & & - & - & - & - & - & - & - \\
\hline Talkeshwara Rasa (Xv) & - & - & - & - & + & - & - & - & - & - & - & - & - & & - & - & - & - & - & - & - \\
\hline $\begin{array}{l}\text { Traymbak } \\
\text { Abhrakam }\end{array}$ & - & - & + & - & - & - & - & - & - & - & - & - & - & & - & - & - & - & - & - & - \\
\hline Tryushnadi Vati & - & - & + & - & + & - & - & - & - & - & - & - & + & & + & - & - & - & - & - & - \\
\hline Yogaottama Vati & - & - & - & + & - & - & - & - & + & - & - & - & + & & - & - & - & - & - & - & - \\
\hline
\end{tabular}

\subsection{Realgar}

Manahshila (Realgar, Arsenic disulphide) is one of the three important arsenical compounds used in Ayurveda as a therapeutic agent. Purified Manahshila is used in several formulations of Ayurveda. The important therapeutic areas of Manahshila use include skin diseases, respiratory diseases, certain ailments of eyes and psychological disorders.

The transdermal delivery of realgar nanoparticles in mouse melanoma skin cancer models and in mouse melanoma cancer cell lines (B16) induces apoptosis and prevents tumor growth via transdermal delivery along with suppression of B16 cell proliferation in a dose-dependent manner after exposed to different concentrations of $\mathrm{As}_{4} \mathrm{~S}_{4}{ }^{[18]}$. Nanorealgar suspension in $\mathrm{SiHa}$ cell line showed induction of apoptosis in a dose-dependent manner with significant increase in cytochrome $\mathrm{c}$ release and activation of caspase- 3 and caspase- 9 but not caspase- $8^{[19]}$. There is a size dependent cytotoxic effect of realgar particles on the human umbilical vein endothelial cell line (ECV-304) where the 
particles of diameters $100 \mathrm{~nm}$ and $150 \mathrm{~nm}$ were found capable to induce the apoptosis in the endothelial cells ${ }^{[20]}$. The anti-tumor effect of realgar on transplanted ovarian SKOV3 carcinoma cells in nude mice showed anti-tumour effect through inducing apoptosis, blocking angiogenesis, inhibiting DNA synthesis and prolonged survival of mice ${ }^{[21]}$. The bioleaching solution of realgar by Acidithiobacillus ferrooxidans was studied for antitumor experiments in hepatic cancer in HepG2 cells (in vitro) and H22 cells transplanted in mice (in vivo) and it showed higher selective affinity to tumor tissues than arsenic trioxide at an LD50 value $(6.63 \mathrm{mg} / \mathrm{kg})^{[22]}$.

\subsection{Copper}

Tamra (Copper) Bhasma one of the metallic preparations in Ayurveda is useful in the treatment of Udara (ascitis), Pandu (anemia), Svasa (bronchial asthma), and Amlapitta (hyperacidity), etc ${ }^{[23]}$. Tamra is attributed with Ashtamahadoshas (eight blemishes) hence proper Shodhana (purification measures)played key role in preparation of Tamrabhasma ${ }^{[24]}$.

In vitro anticancer efficacy of the bare copper nano-particles (CNPs), $\mathrm{CuSO}_{4}$, and copper-loaded chitosan nanoparticles (CuCNPs) were studied in MG-63 osteosarcoma cancer cells, showed concentration-dependent cytotoxic effect by $\mathrm{CuSO}_{4}$ and CuCNPs. There was superior anticancer effect of $\mathrm{CuCNP}$ due to the generation of higher mitochondrial ROS level compared to control $^{[25]}$. Copper oxide nanoparticles synthesised using the extract of Acalypha indica were evaluated for its cytotoxic potential against MCF-7 breast cancer cell lines, showed the activity at $\mathrm{IC}_{50}$ value of $56.16 \mu \mathrm{g} / \mathrm{ml}$ with the size of nanoparticles ranged from 26 to $30 \mathrm{~nm}^{[26]}$. Copper oxide nanoparticles (CuONPs) induce autophagy in human breast cancer cell line (MCF7) in a time and dose-dependent manner, suggesting employing a combination of CuONPs along with the autophagy inhibitor to induce apoptosis in breast cancer cells ${ }^{[27]}$. Ficus religiosa leaf extract was employed to formulate copper oxide nanoparticles and studied for its anticancer potential in human A549 lung cancer cells showed apoptotic effect by the generation of reactive oxygen species (ROS) involving the disruption of mitochondrial membrane potential in the cells ${ }^{[28]}$. CuONPs in the concentration ranging from 2 to $50 \mu \mathrm{g} / \mathrm{ml}$ were found to induce cytotoxicity in human hepatocellular carcinoma HepG2 cells in dose-dependent manner, also suggesting mitochondrial-mediated pathway involved in apoptosis ${ }^{[29]}$.

\subsection{Silver}

Rajatabhasma or incinerated silver is widely used in ayurvedicherbo-mineral preparations, used along with different
Anupanas (adjuvant) in several diseases. It stokes agni and improve appetite, it augments longevity and intelligence ${ }^{[30]}$.

A series of silver (I) complexes were synthesised and studied for its cytotoxic activity against B16 (murine melanoma) and 10T1/2 (murine fibroblasts) cells showed low toxicity to noncancerous $10 \mathrm{~T} 1 / 2$ cells and two of the complexes showed greater cytotoxicity against B16 cells ${ }^{[31]}$.The gold (I) imidazolium metal complexes and their silver precursors were evaluated against NCIH460 lung cancer cells along with cisplatin showed similar anticancer efficacy ${ }^{[32]}$. Biogenically synthesised silver nanoparticles using Sesbania grandiflora leaf extract studied for its in vitro cytotoxic effect against human breast cancer (MCF-7) cells showed an immediate induction of cellular damage in terms of loss of cell membrane integrity, oxidative stress and apoptosis suggesting it as a biogenic anti-cancerous agent ${ }^{[33]}$. Silver nanoparticles using the aqueous extract of Origanum vulgare (Oregano) were characterized and evaluated against human lung cancer A549 cell line showed direct dose-response relationship and a minimum of $100 \mathrm{~g} / \mathrm{ml}$ of silver nanoparticles found well enough to induce $50 \%$ of cell mortality ${ }^{[34]}$. Synthesised AgNPs using culture supernatant of Bacillus funiculus were studied against MDA-MB-231 breast cancer cells at various concentrations (5 to $25 \mu \mathrm{g} / \mathrm{mL}$ ) for 24 hours showed dosedependent cytotoxicity by nuclear fragmentation concluding it as a potential alternative agent for human breast cancer therapy ${ }^{[35]}$.

\subsection{Gold}

Gold bhasma are widely used as therapeutic agent in Ayurvedic formulations. It is beneficial to heart, augments strength, memory, intelligence and complexion, detoxifies the toxic metabolites and said to possess Rasayana properties ${ }^{[36]}$.There has been an emerging interest in drug discovery strategies where natural products and traditional medicines are re-emerging as attractive option and hence one can see the renewed interests in agents like Swarnabhasma ${ }^{[37]}$. In modern medicine, gold nanoparticles plays significant role in drug delivery system as they are found to be capable of encapsulating active drugs and targeting. A completely novel technology using colloidal gold nanoparticles has been demonstrated in the field of particle-based tumor-targeted drug delivery ${ }^{[38]}$. Methotrexate (MTX), a chemotherapeutic agent, conjugated with gold nanoparticles showed cytotoxic effect on number of tumour cell lines compared to same dose of free MTX, along with suppression of tumour growth mouse ascites model of Lewis lung carcinoma (LL2) ${ }^{[39]}$. The AuNPs synthesized from aqueous chlorauric acid solution were assessed for cytoxicity in MRC-5 human fetal lung fibroblast cell lines, showed oxidative DNA damage along with inhibition of 
cellular proliferation ${ }^{[40]}$. Ultra small gold nanoparticles (AuNPs) coated with Tiopronin ( 2 to $15 \mathrm{~nm}$ ), evaluated in monolayer breast cancer cells, a MCF-7 tumor spheroid model, and in vivo tumor tissue in mice showed higher levels of accumulation in tumours and high degree of penetration behaviour ${ }^{[41]}$.

\section{DISCUSSION}

Bhasmas are the mutli-elemental drugs. Bajaj and Vohora (2000) have reported that Swarnabhasma consists of $46.9 \%$ gold and 0.15ppm mercury. Goel and Sairam (2002) have reported that Tamrabhasma contains copper oxide between 44.45 to $66.13 \%$, ferric oxide less than $6.03 \%$, and less than $2.75 \%$ sulphur ${ }^{[42]}$. XANES- and EXAFS- based analysis of Hg-based Nano-drug Rasasindura, carried out in Bhabha Atomic research centre, revealed composition of Single phase $\alpha-\mathrm{HgS}$ nanoparticles (size 20 nm), free of $\mathrm{HgO}$ or organic molecules, and better controlled structural parameters (size dispersion, coordination configuration $^{[43]}$. There are number of analytical modern tools and techniques to study the particle size of engineered metallic nanoparticles using SEM, XRD, TEM, EDAX etc. technologies, which are also adopted to investigate various Ayurvedic Bhasma. Analysis of Swarnamakshika bhasma using SEM (Scattering Electron Microscopy) shows particles size of 1 to $2 \mu \mathrm{m}^{[44]}$. Transmission Electron Microscopy(TEM) analysis of nanoparticulate fraction of Jasada Bhasma particles shows the appearance of 15-25 $\mathrm{nm}$ particles in the sample, and size of the particles present in un-fractionated part of Yashada Bhasmawas 0.85-1.35 $\mu \mathrm{m}$ with the mean size $1.2 \mu \mathrm{m}$ in Dynamic Light Scattering (DLS) analysis ${ }^{[45]}$. Sieve analysis of lauhabhasma indicates that $30 \%$ (by mass) of the particles were smaller than 45 $\mu \mathrm{m}$ with the sub-sieve size distribution ranged between 1.7 and 10.4 $\mu \mathrm{m}$, whereas in SEM analysis reported irregular shaped aggregates of nano-dimensional particles $(\sim 28 \mathrm{~nm})^{[46]}$. The size of gold crystallites in Swarnabhasma using XRD analysis lie in the range 23 to $37 \mathrm{~nm}$ with average particle size be $57 \mathrm{~nm}$ with globular morphology ${ }^{[47]}$. XRD analysis of Vangabhasma shows particle size of 12 to $53 \mathrm{~nm}^{[48]}$.

Thus, from the above evidences and studies carried out by the scholars at various platforms, it provides a strong inference that Ayurvedic Bhasma are nearer to nano-crystalline materials and can play a strong role in the emerging era of nano-medicine and can serve as an excellent tool for the development of nanomedicine, to be an efficient therapeutic cure in dreadful disease like cancer.

Gold nanoparticles in Swarna Bhasma at $27 \pm 3 \mathrm{~nm}$ size have been found effective in symptoms of arthritis and at $4 \mathrm{~nm}$ size helped in increased apoptosis in B-chronic lymphocytic leukemia ${ }^{[49]}$.The size and shape of nanomedicine is directly proportional to their activity in desired field. The number and type of puta in traditional incineration process is responsible for the pharmacological activity of the Bhasma.

In Ayurveda system of medicine a holistic approach towards ailments is adopted. On reviewing the publications, the methodology adopted by the various Ayurvedic physician in relation to cancer management and scientific studies published in various journals can be enumerated and is as follows.

In 1960, treatment of Hodgkin's Lymphoma patient with bone metastasis were successfully treated with an Ayurvedic preparation called Valipani developed by Vaidya Chandra Prakash, which consists processed mercury, sulphur, iron, harad (Terminalia chebula) along with bhilava (Semecarpus anacardium), amla (Emblica officinalis), ginger (Zingiber officinale) and honey, which was primarily given to the patient to strengthen the bone marrow function ${ }^{[50]}$.

In $1980 \mathrm{~s}$, a new metal based formulation called Navjeevan was prepared and it was consisting of processed and detoxified silver, mercury, sulphur and arsenic trioxide in 1:1:1:1:1 ratio along with some Ayurvedic herbs like Nirvishi (Delphinium denudatum) and ground with rose (Rosa rubiginosa), sandalwood (Santalum album), Gajwan (Onosma bracteatum), and Latakasturi (Hibiscus abelmoschus) ark and it was administered along with Ayurvedic medicines Kamdudha Rasa, Kehruba Pishti and Leucas aspeca root and found to be effective in the treatment of myeloma and lymphoma. Navjeevan is aimed to restore the homeostasis thus reversing the proliferation of neoplastic cells in bone $\operatorname{marrow}^{[51]}$.

In one of the study which was aimed to detect the effect of Swarna Bhasma (SB) on solid malignancies. A total of 43 patients were included in this study received $\mathrm{SB}(50 \mathrm{mg} / \mathrm{kg} /$ day $)$, were followed up monthly for 1 year, then 6 monthly for 5 years. Seventeen patients showed response. In the rectal cancer group around $70 \%$ (i.e, 7 out of 10 patients) showed best response out of all solid malignancies. There were around nearly $41.02 \%$ patients who showed survival for 1 year after treatment, but after 5 years it was reduced to $15.38 \%{ }^{[52]}$.

A novel Herbomineral preparation Las01containing a number of herbs and different types of inorganic minerals such as mercury which has been extensively purified through 75 steps as per Kupipakva Rasayana technique, which was said to be an anticancer drug in the form of bhasma. This herbomineral drug was standardized and its anti-cancerous effects were studied in 
the human cell lines, the MCF-7 and HeLa cancer cell lines, which was studied further for its acute and sub-chronic toxicity study. Cytotoxic effects were evaluated on cell line using MTT and LDH methods, respectively and it was found that inhibited proliferation of both MCF-7 and HeLa cervical cancer cells was in a dosedependent manner. It was observed that there was decrease in the viability of cancer cells when the concentration was increased (10 to $500 \mathrm{mg} / \mathrm{L})$. There was no significant change in total WBC count, haemoglobin content, and biochemical parameters in animals treated upto 40-fold doses for a period of 14 days. Subchronic administration of these drugs did not produce any toxic effect. The preparation Las01 was also found to be devoid of toxicity both in animals as well as in human subjects ${ }^{[53]}$.

On scrutinizing the available literature on Cancer published in various journals and collating the formulations described in classical literature, it can be inferred that Ayurveda can be a promising tool in the management of life-threatening diseases including cancer. Nanoparticles of Arsenicals, Copper, Silver,Gold etc. has been utilized by various scholars for theiranticancer activities. Similarly, in Arbudahara Yogas (formulations), Bhasma of these metal and minerals are mentioned as major or minor ingredients. These formulations are compiled and tabulated, which can provide a strong database for further researches in the area of cancer management. However, Proper Pre-clinical and Clinical trials along with suitable toxicity and safety data is required for generating evidences, so that these formulations can be utilized as line of treatment in Cancer.

\section{CONCLUSION}

In the past, metal-based compounds were widely used in the treatment of disease conditions, but the lack of clear distinction between the therapeutic and toxic doses was a major challenge. In recent times, there has been an upsurge of activities relying on the structural information, aimed at improving and developing other forms of metal-based compounds. However, the classical Ayurvedic Bhasmas,has distinct mechanism of action from conventional anti-cancer agents. In line with this, many more metal-based compounds can be utilized or building the entire new compound with enhanced safety and cytotoxic profile. on Thus, from the above evidences and studies carried out by the scholars at various platforms, it provides a strong inference that Ayurvedic Bhasma are nearer to nano-crystalline materials and can play a strong role in the emerging era of nano-medicine and can serve as an excellent tool for the development of nanomedicine, to be an efficient therapeutic cure in dreadful disease like cancer.However, because of increased emphasis on the clinical relevance of metal-based complexes, a few of these drugs are currently on clinical trial and many more are awaiting ethical approval to join the trial. Lack of publication among practicing physicians is also a matter of great concern.

CONFLICT OF INTEREST The authors declare no conflict of interest.

CONTRIBUTORS Dr. Anu contributed to literature review and draft preparation. Dr. Pramod, Dr. Galib and Dr. Prajapati contributed to the conceptualization of topic, analysis and finalisation of the draft.

\section{REFERENCES}

1. who.int. World Health Organistaion; c2018 [cited at 11.00 on 20-10-18] Available from https://www.who.int/cancer/en/

2. gco.iarc.fr. Globocon 2018; c2018 [cited at 11.20 on 20-10-18] Available from http://gco.iarc.fr/today/data/factsheets/cancers/39-All-cancers-factsheet.pdf

3. cancerindia.org.in. Globocan 2018: India Factsheet; c2018 [cited at 11.28 on 20-10-18] Available from http://cancerindia.org.in/globocan2018-india-factsheet/

4. Gacche RN, Shaikh RU, Pund MM. In vitro evaluation of anticancer and antimicrobial activity of selected medicinal plants from Ayurveda. Asian J Trad Med 2011;6(3):1-7.

5. G Grothaus P, M Cragg G, J Newman D. Plant natural products in anticancer drug discovery. Current Organic Chemistry 2010;14(16):178191.

6. Shoeb M. Anticancer agents from medicinal plants. Bang J Pharmacol 2006;1:35-41.

7. Sharma PV, editor, (Reprint: 2013). ShushrutaSamhita Vol.II NidanaSthana; Chapter11, Verse 14-15. Varanasi: Chowkhambha Visvabharati 2013; p.75.

8. Singh RH. An assessment of the ayurvedic concept of cancer and a new paradigm of anticancer treatment in Ayurveda. The Journal of Alternative \& Complementary Medicine 2002;8(5):609-14.

9. Prakash S. editor, (1st ed.). Commentary on Rasendra Sara Sanghraha of Shri Gopal Krishna, Chapter 1, Verse 4. Varanasi: Krishnadas Academy $1994 ;$ p.5.

10. Sarkar PK, Chaudhary AK. Ayurvedic Bhasma:the most ancient application of nanomedicine. Journal of Scientific \& Industrial Research 2010;69:901-5.

10. ASTM International. E2456-06 Terminology for nanotechnology. West Conshohocken, PA: ASTM International, 2006.

12. Sharma Hariprapanna Pandit, Rasayogasagara, Vol. 1\&2, Varanasi: Chawkhamba Krishnadas Academy, $1^{\text {st }}$ edition, 1983.

13. Shen ZX, Chen GQ, Ni JH, Li XS, Xiong SM, Qiu QY, Zhu J, Tang W, Sun GL, Yang KQ, Chen Y. Use of arsenic trioxide (As2O3) in the treatment of acute promyelocyticleukemia (APL): II. Clinical efficacy and pharmacokinetics in relapsed patients. Blood 1997;89(9):3354-60.

14. Bazarbachi A, El-Sabban ME, Nasr R, Quignon F, Awaraji C, Kersual J, Dianoux L, Zermati Y, Haidar JH, Hermine O. Arsenic Trioxide and Interferon-Synergize to Induce Cell Cycle Arrest and Apoptosis In 
Human T-Cell Lymphotropic Virus Type I-Transformed Cells. Blood 1999;93(1):278-83.

15. Zhang W, Ohnishi K, Shigeno K, Fujisawa S, Naito K, Nakamura S, Takeshita K, Takeshita A, Ohno R. The induction of apoptosis and cell cycle arrest by arsenic trioxide in lymphoid neoplasms. Leukemia 1998;12(9):1383.

16. Zheng J, Deng YP, Lin C, Fu M, Xiao PG, Wu M. Arsenic trioxide induces apoptosis of HPV16 DNA-immortalized human cervical epithelial cells and selectively inhibits viral gene expression. International journal of cancer 1999;82(2):286-92.

17. Shen ZY, Tan LJ, Cai WJ, Shen J, Chen C, Tang XM, Zheng MH. Arsenic trioxide induces apoptosis of oesophageal carcinoma in vitro. International Journal of Molecular Medicine 1999;4(1):33-40.

18. Zhao QH, Zhang Y, Liu Y, Wang HL, Shen YY, Yang WJ, Wen LP. Anticancer effect of realgar nanoparticles on mouse melanoma skin cancer in vivo via transdermal drug delivery. Medical Oncology 2010;27(2):203-12

19. Cheng YX, Liu R, Wang Q, Li BS, Xu XX, Hu M, Chen L, Fu Q, Pu DM, Hong L. Realgar-induced apoptosis of cervical cancer cell line Siha via cytochrome c release and caspase- 3 and caspase- 9 activation. Chinese Journal of Integrative Medicine 2012;18(5):359-65.

20. Deng Y, Xu H, Huang K, Yang X, Xie C, Wu J. Size effects of realgar particles on apoptosis in a human umbilical vein endothelial cell line: ECV-304. Pharmacological Research 2001;44(6):513-8.

21. Chen WX, Zhang F, Yang HC, LIU S, GUO X, LI J. The effect of realgar on apoptosis of transplanted ovarian SKOV3 carcinoma cells in nude mice. Tumor 2007;27(10):787-90.

22. Zhang X, Xie QJ, Wang X, Wang B, Li HY. Biological extraction of realgar by Acidithiobacillusferrooxidans and its in vitro and in vivo antitumor activities. Pharmaceutical biology 2010;48(1):40-7.

23. Mishra GS. editor, (reprint 2016). Commentary on Ayurveda Prakash of AcharyaShriMadhava, Chapter 3, Verse 147. Varanasi: Chaukhamba Bharati Academy; 2007; p. 373.

24. Mishra GS. editor, (reprint 2016). Commentary on Ayurveda Prakash of Acharya Shri Madhava, Chapter 3, Verse 145-146. Varanasi: Chaukhamba Bharati Academy; 2007; p. 373

25. Ai JW, Liao W, Ren ZL. Enhanced anticancer effect of copper-loaded chitosan nanoparticles against osteosarcoma. RSC Advances 2017;7(26):15971-7.

26. Sivaraj R, Rahman PK, Rajiv P, Narendhran S, Venckatesh R. Biosynthesis and characterization of Acalyphaindica mediated copper oxide nanoparticles and evaluation of its antimicrobial and anticancer activity. Spectrochimica Acta Part A: Molecular and Biomolecular Spectroscopy 2014;129:255-8.

27. Laha D, Pramanik A, Maity J, Mukherjee A, Pramanik P, Laskar A, Karmakar P. Interplay between autophagy and apoptosis mediated by copper oxide nanoparticles in human breast cancer cells MCF7. Biochimicaet Biophysica Acta (BBA) - General Subjects 2014;1840(1):1-9.

28. Sankar R, Maheswari R, Karthik S, Shivashangari KS, Ravikumar V. Anticancer activity of Ficus religiosa engineered copper oxide nanoparticles. Materials Science and Engineering: C 2014;44:234-9.

29. Siddiqui MA, Alhadlaq HA, Ahmad J, Al-Khedhairy AA, Musarrat J, Ahamed M. Copper oxide nanoparticles induced mitochondria mediated apoptosis in human hepatocarcinoma cells. PloS one 2013;8(8):e69534.
30. Kulkarni DA, editor, (reprint 2010). Commentary on Rasaratna Samuchchaya of Vagbhattacharya, Chapter 5, Verse 40, Meharchand Lachmandas Publications, 2010; p.99.

31. Kalinowska-Lis U, Felczak A, Chęcińska L, Szabłowska-Gadomska I, Patyna E, Małecki M, Lisowska K, Ochocki J. Antibacterial activity and cytotoxicity of silver (I) complexes of pyridine and (Benz) imidazole derivatives. X-ray crystal structure of [Ag (2, 6-di $(\mathrm{CH} 2 \mathrm{OH})$ py) 2] NO3. Molecules 2016;21(2):87.

32. Siciliano TJ, Deblock MC, Hindi KM, Durmus S, Panzner MJ, Tessier CA, Youngs WJ. Synthesis and anticancer properties of gold (I) and silver (I) N-heterocyclic carbene complexes.Journal of Organometallic Chemistry 2011;696(5):1066-71.

33. Jeyaraj M, Sathishkumar G, Sivanandhan G, MubarakAli D, Rajesh M, Arun R, Kapildev G, Manickavasagam M, Thajuddin N, Premkumar K, Ganapathi A. Biogenic silver nanoparticles for cancer treatment: an experimental report. Colloids and surfaces B: Biointerfaces 2013;106:8692.

34. Sankar R, Karthik A, Prabu A, Karthik S, Shivashangari KS, Ravikumar $\mathrm{V}$. Origanumvulgare mediated biosynthesis of silver nanoparticles for its antibacterial and anticancer activity. Colloids and Surfaces B: Biointerfaces 2013;108:80-4.

35. Gurunathan S, Han JW, Eppakayala V, Jeyaraj M, Kim JH. Cytotoxicity of biologically synthesized silver nanoparticles in MDA-MB-231 human breast cancer cells. BioMed Research International 2013.

36. Mishra GS, editor, (reprint 2016). Commentary on Ayurveda Prakash of Acharya Shri Madhava, Chapter 3, Verse 27-29. Varanasi: Chaukhamba Bharati Academy; 2007; p. 350.

37. Patwardhan B, Vaidya AD. Natural products drug discovery: Accelerating the clinical candidate development using reverse pharmacology approaches. Indian J Exp Biol 2010;48:220-7.

38. Ghosh P, Han G, De M, Kim CK, Rotello VM. Gold nanoparticles in delivery applications. Adv Drug Deliv Rev 2008;60:1307-15.

39. Chen YH, Tsai CY, Huang PY, Chang MY, Cheng PC, Chou CH, Chen DH, Wang CR, Shiau AL, Wu CL. Methotrexate conjugated to gold nanoparticles inhibits tumor growth in a syngeneic lung tumor model. Molecular Pharmaceutics 2007;4(5):713-22.

40. Li JJ, Zou LI, Hartono D, Ong CN, Bay BH, Lanry Yung LY. Gold nanoparticles induce oxidative damage in lung fibroblasts in vitro. Advanced Materials 2008;20(1):138-42.

41. Huang K, Ma H, Liu J, Huo S, Kumar A, Wei T, Zhang X, Jin S, Gan Y, Wang PC, He S. Size-dependent localization and penetration of ultrasmall gold nanoparticles in cancer cells, multicellular spheroids, and tumors in vivo. ACSnano 2012;6(5):4483-93.

42. Arya RK. Characterization of Bio-Active Nanoparticles-Bhasma an Indian Ayurvedic Drug.Indian Journal of Pharmaceutical Education and Research 2014;48(1):61-8.

43. Ramanan N, Lahiri D, Rajput P, Varma RC, Arun A, Muraleedharan TS, Pandey KK, Maiti N, Jha SN, Sharma SM. Investigating structural aspects to understand the putative/claimed non-toxicity of the Hg-based Ayurvedic drug Rasasindura using XAFS. Journal of synchrotron radiation 2015;22(5):1233-41.

44. Mohaptra S, Jha CB. Physicochemical characterization of Ayurvedic bhasma (Swarnamakshikabhasma): An approach to standardization. International journal of Ayurveda research 2010;1(2):82. 
45. Bhowmick TK, Suresh AK, Kane SG, Joshi AC, Bellare JR Physicochemical characterization of an Indian traditional medicine, JasadaBhasma: detection of nanoparticles containing non-stoichiometric zinc oxide. Journal of Nanoparticle Research 2009;11(3):655-64.

46. Krishnamachary B, Pemiah B, Krishnaswamy S, Krishnan UM, Sethuraman S, Sekar RK. Elucidation of a core-shell model for LauhaBhasma through physico-chemical characterization. Int J Pharm Pharm Sci 2012;4(2):644-9.

47. Brown CL, Bushell G, Whitehouse MW, Agrawal DS, Tupe SG, Paknikar KM, Tiekink ER. Nanogold-pharmaceutics (i) The use of colloidal gold to treat experimentally-induced arthritis in rat models; (ii) Characterization of the gold in Swarnabhasma, a microparticulate used in traditional Indian medicine. Gold Bulletin 2007;40(3):245-50.

48. RudrammaHiremath DC, Narang KK. Vangabhasma and its XRD analysis.Ancient science of life 2010;29(4):24.

49. Paul S, Chugh A. Assessing the role of Ayurvedic 'bhasms' as ethno-nanomedicine in the metal based nanomedicine patent regime. J Intellect Prop Rights 2011;16:509-15.
50. Prakash B. Indigenous approach to combat cancer. Health Administrator 2005;17:169-71.

51. Prakash VB. Effect of metal based Ayurvedic formulations in the patients of acute promyelocyticleukemia - a pilot study. Monograph submitted to Central Council for Research in Ayurveda \& Siddha, New Delhi, 2003

52. Das S, Das MC, Paul R. SwarnaBhasma in cancer: A prospective clinical study. AYU 2012;33(3):365.

53. Sheikh S, Srivastava A, Tripathi R, Tripathi S, Trivedi VP, Saxena RC. Toxicity of a novel herbomineral preparation Las01 on human cancer cell lines and its safety profile in humans and animals. Evidence-Based Complementary and Alternative Medicine 2012. 